\title{
МАТЕРІАЛОЗНАВСТВО
}

\author{
UDC 539.6:656-044.923:[711.552]
}

\author{
I. O. BONDARENKO ${ }^{1 *}$, L. O. NEDUZHA ${ }^{2 *}$ \\ ${ }^{1 *}$ Dep. «Track and Track Facilities», Dnipro National University named after Academician V. Lazaryan, Lazaryana St., 2, \\ Dnipro, Ukraine, 49010, tel. +38 (063) 80221 80, e-mail irina_bondarenko@ua.fm, ORCID 0000-0003-4717-3032 \\ $2^{2 *}$ Dep. «Theoretical and Structural Mechanics», Dnipro National University named after Academician V. Lazaryan, Lazaryana \\ St., 2, Dnipro, Ukraine, 49010, tel. +38 (067) 81051 65, e-mail nlorhen@i.ua, ORCID 0000-0002-7038-3006
}

\section{THE PROBLEM OF A LACK OF MATERIAL BEHAVIOUR DATA FOR RISK ASSESSMENT}

Purpose. The main purpose of this work is to provide theoretical support for the need to expand data on changes in the material behaviour under dynamic loads when railway track risk assessment over time due to railway track elements deformability. Methodology. For the research, an original model of railway track design described using the original method based on the ability of elastic waves to propagate energy of power pulses in space and time, as well as a model describing materials as discrete substances were used. Findings. It has been established that the properties of the material affect the deformability of the elements and the design of the railway track; the main parameter in the study of deformability processes is time; material, as a substance, consists of atoms and molecules, and therefore is not continuous; internal physical processes determine changes in the behaviour of the material of an element. Originality. It has been proposed to develop classifications of changes in the physical properties of materials according to the probability of irreversible deformations and the impossibility of deformations, as well as classifications of changes in the mechanical properties of materials according to the probability of the defect appearance and changing the material structure. Practical value. The ability to simulate analytically any physical processes occurring inside elements due to the proposed method allows combining the influence of mechanical and physical effects into a single calculation. This enables to assess the probability of appearing defects in elements under certain dynamic loads when assessing the railway track risk over time due to railway track elements deformability.

Keywords: risk; deformations; materials; defect; deformability; physical and mechanical characteristics

\section{Introduction}

Generally, the design of the railway track is the presence of a rail-sleeper grid laid on one of the two structures of the base: a) the ballast layer and the foundation soil (including sub-ballast layers) or bridges; b) artificial structure (bridges, flyovers, tunnels).

Elements of the rail-sleeper grid, bridges, and tunnels are solid-state structures, the materials of which are metal, wood, reinforced concrete, and polymers. The materials used for the ballast, subballast layers and foundation soil are bulk materials and represented by various soils.

The abilities of materials of railway track elements to absorb and transmit mechanical influ- ences are very different. The material properties of the track elements determine the nature of the deformation of the railway track elements under mechanical stress. Physical (density, water saturation, electrical and thermal conductivity, magnetization, temperature coefficients of linear and volume expansion, etc.) and mechanical (strength, elasticity, ductility, brittleness, impact resistance, hardness, abrasion, wear, etc.) properties of materials determine the reaction of elements and track designs under the rolling stock's effects and the environment and also affect the technical conditions of elements and track designs.

During operation, under the influence of rolling stock and the environment, changes occur both in the technical conditions of the elements and in the 
railway track design. Therefore, there are such limiting technical conditions of both elements and track designs that are criteria for unsuitability for their normal operation (that is, unsuitability for the second limit state, which is also called deformability unfitness). Without these criteria, the task of ensuring the minimization of the life cycle costs of the elements and track designs while maximizing the RAMS (reliability, availability, maintenance, and safety, IEC 62278: 2002, EN 50126-1-2017, IEC 60300-3-3: 2017) of functioning systems is impossible.

During operation under the rolling stock's influence and the environment, there are:

- material deformability - the ability of the material to respond to physical factors (thermal, aqueous, acoustic, electrical, gravitational, radiation (nuclear, X-ray, etc.)) by changing shape and size depending on the physical properties of the material;

- elements deformability - the ability of elements, like products made from a certain material with a certain geometry, to respond to mechanical stresses depending on the physical and mechanical material properties and operating modes (loading speed, temperature, exposure to the environment and other factors),

- design deformability - the total deformability of its elements at which design's elements not only can change shape, size, and volume but also move due to the deformability of other elements that make up the design.

The study of the deformability processes occurs simultaneously in several directions. So, specialists in studying the properties of the materials are exploring the possibility of improving their quality by using various additives to adapt the operation of the elements under the influence of various climatic and operational conditions [4, 17]. To increase the wear resistance and extend the life of the elements, structure designers study the influence of the geometric shapes of the elements on the features of the design for certain contact conditions of the elements that occur during operation $[1,6,16]$. Design experts examine the correlations of operating conditions with the occurrence of faults and defects $[11,13,18,26]$ to assess risks. And with the help of diagnostic studies, based on statistical measurements, there is an assessment, control, and verification of correlation dependencies [7, 19, 21, 23-24]. Scientific institutions, using the results of the above specialists, develop models [12, 14-15, $20,22,25]$ for studying and predicting the operation of elements and structures in various conditions, which are subsequently used as tools for studying deformability.

This approach to studying of the deformability processes uses a huge amount of information obtained not only by the above-mentioned specialists but also by experts in the development of methods and equipment for measuring, recording, and processing the necessary measurement values. And the main parameter that unites all researchers is time, i.e. the ability to measure, record, evaluate, monitor, and predict the processes of deformability for both short and long time periods. Therefore, the paper presents the results of the theoretical support for the need to expand data on changes in time of the physical and mechanical characteristics of materials of track design elements under the influence of rolling stock and the environment when railway track risks assessment over time due to railway track elements deformability.

\section{Purpose}

The main purpose of this work is to provide theoretical support for the need to expand data on changes in the material behaviour under dynamic loads when railway track risk assessment over time due to railway track elements deformability. The object of the study is the deformability as a factor of appearing defects in elements under dynamic loads when railway track risk assessment over time. The subject of the study is the internal physical processes to determine changes in the behaviour of the material of an element when railway track risk assessment over time due to railway track elements deformability.

\section{Methodology of investigation}

When a rolling stock travels along a track structure, the process of transferring dynamic effects from rolling stock to a track structure and the reaction of a track to a rolling stock effect is carried out by wheel-rail contact. This process is quite complex, its features are:

- the statistical variation of the types of wheel contact with the rail, the contact point relative to the rail head, the parameters of the contact areas of the wheels and rails, as well as the direction of the 
interaction forces on the contact areas depending on the position of the wheelset relative to the rail track, as well as the technical conditions of the wheels and rail tracks;

- the statistical spread of the magnitude and direction of the interaction forces depending on the movement mode of the rolling stock, type of track structures and rolling stock, track plan and profile;

- the complex cyclic nature of the repeatability of the impact of the rolling stock wheels on the track section, depending on the designs of locomotives and wagons in a train.

On the one hand, deformability predicting of railway track elements in time is the task of determining the conditions under which a single action of a wheel on railway track sections will cause deformations or defects in the railway track elements and design. On the other hand, it is a task to determine how the impact of a certain spectrum of rolling stock on a certain track section during the operation of the track affects the gradual accumulation of deformations and the development of defects in the railway track elements and design. Both tasks are unsolvable without data on changes in time of the physical and mechanical characteristics of materials of track design elements under the influence of rolling stock and the environment.

In other words, to predict changes in the state of any railway track element, under the dynamic influence of the rolling stock during operation, it is necessary to have information about emergence reasons of internal deformations and stresses with different characteristics (direction, value, rate of change of value, time of exposure and the number of occurrence of exposure). And how they affect the changes in the physical and mechanical material characteristics, depending on the structure, humidity, and temperature of the material at the time of exposure of strains and stresses inside the elements.

Based on theories of elasticity and propagation of elastic waves a method was developed to determine the processes leading to a change in time of the local values of strains and stresses inside the elements, [2, 3, 8-10]. The main advantage of the proposed modeling method is the use of the ability of elastic waves to propagate the energy of force actions (pulses) in space and time.

The materials properties determine the propagation velocity inside the elements of transverse and/or longitudinal waves. The magnitude and the direction of the mechanical action determine the direction and value of the movements of the particles inside the element. Fig. 1, $a$ shows the direction of the movement of both all kind of wave propagation with respect to the direction of the acting force and of particles under the longitudinal waves action. Fig. 1b shows the directional movement of particles under the transverse waves action. Figure 1 displays the directions of particle movement for one of the cross-sections of the spatial distribution of spherical transverse and longitudinal waves.

$a$

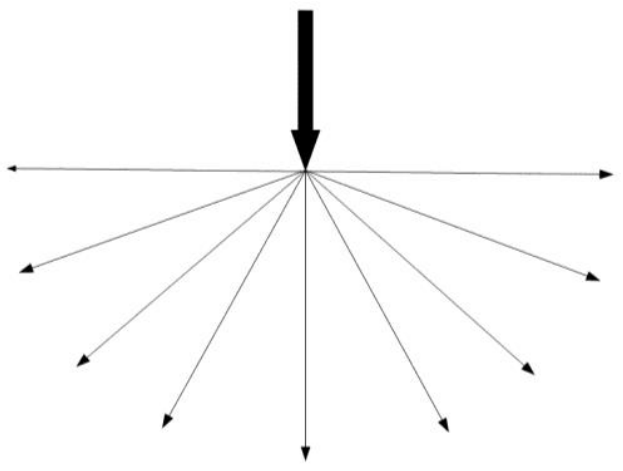

$b$

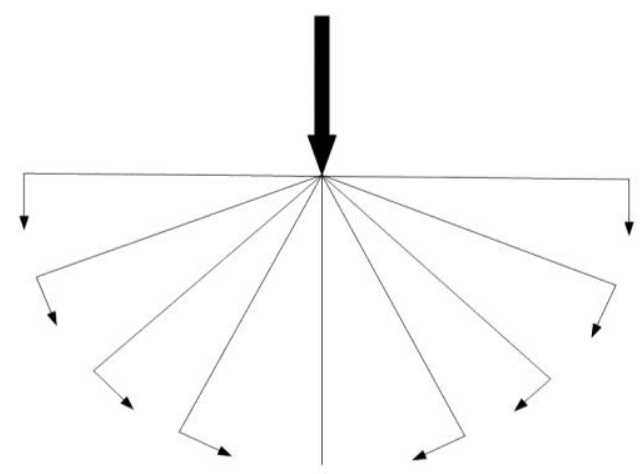

Fig. 1. Movement direction of both kinds of wave propagation with respect to the direction of the acting force and particles under the action of:

$a$ - longitudinal waves; $b$-transverse waves

Along the direction of force action, all the energy of the force action moves the particles by means of longitudinal waves. In a direction perpendicular to the direction of force, the particles move only through transverse waves. In all other wave propagation directions, the particles are moved by two types of waves. The processes of reflection and refraction of waves depend on the 
geometry of the elements and their connection in the structure.

Unlike existing calculation methods, the proposed calculation method allows us to analyze:

- the oscillations amplitude and frequency of each object in the model, under the influence of variable moving pulses in time;

- the reaction of each object in the model to the action of an impulse in time;

- qualitative and quantitative changes in deformation processes in modelling objects in time;

- the amount of energy spent on absorbing of momentum by each object in the model; elastic and residual deformations; internal and external friction forces; dissipative processes inside objects.

Thus, using the proposed method allows us to evaluate the simulation object for reliability, availability, maintainability, and safety under various operating conditions of the object.

The main aim of this simulation was the ability to simulate analytically any physical processes occurring inside elements. Due to the fact that any effect can be represented as a vector of the change in the amount of energy over time at any point of the simulation object, depending on the physical and mechanical and geometric parameters of the simulation object, the proposed method allows combining the influence of mechanical and physical effects into a single calculation.

However, one question remains unresolved. It is connected with the fact that the construction of a material model is based on the concept of the material continuum, that is, it is assumed that the substance of the object completely fills the space. Modelling objects in this way ignores two facts:

- a material, as a substance, consists of atoms and molecules, and therefore is not continuous;

- internal stresses characterize the interaction of internal forces directed against the attractive force of bound atoms or molecules of a material.

Consideration of these facts necessitates the expansion of data on changes in time of the physical and mechanical materials characteristics of track structure elements under the influence of rolling stock and the environment.

A mechanical impulse, acting on an object, transfers a certain amount of energy to it, which is absorbed and transmitted inside the element by force waves creating force fields. The latter cause the material particles to move, causing various physical processes to occur inside the element with a change in time:

- material local density (change in the distance between particles under the influence of force waves);

- material local temperature (due to friction during the displacement of particles or inelastic collision of force waves);

- material compressibility (due to a change in the local density of the material and due to this change in the movement of particles under the force waves action);

- element volume (as a combination of the physical processes described above).

These physical processes cause: changes in the particle's local concentration, changes in the local volume inside the element, changes in the local velocity of particles and, according to the second law of motion, can be written as:

$$
\begin{aligned}
F(t)=R(t)= & d(m v) / d t= \\
& =d(p V v) / d t=d\left(n m_{0} V v\right) / d t
\end{aligned}
$$

where $F(t)$ - is the impulse external force acting on the object; $R(t)$ - is the momentum of the force field acting inside the object; $m$ - is the mass of the object, absorbing the influence of an external impulse, by means of a force field pulse, which is formed on the basis of a superposition of force waves; $a$ - is the acceleration of particles exposed to the force field; $p$ - is the material density of the object; $V$ - is the object's volume, absorbing the influence of an external impulse, by means of a force field pulse, which is formed on the basis of a superposition of force waves; $t-$ is the time; $v-$ is the velocity of particles exposed to the force field; $m_{0}$ - is the mass of one molecule; $n$ - concentration, the number of molecules per unit volume.

According to the first law of thermodynamics, for any volume it is true:

$$
\delta K(t)+\delta U(t)+\delta A(t)=\delta Q(t)
$$

where $\delta K(t)$ is the change in the kinetic energy of the body; $\delta U(t)$ - change in the internal energy of the body; $\delta A(t)$ - change in work performed by 
external forces; $\delta Q(t)$ - is the change in thermal energy.

In this formula, the values of the terms $\delta A(t)$ and $\delta Q(t)$ are exactly known. The value of $\delta K(t)$ is not known since the initial velocity and direction of motion of bound atoms or molecules of the material in the studied location of the object is unknown. And also, there is no information on how a change in the distance between bound atoms or molecules affects $\delta U(t)$. Therefore, there is a need to classify the parameters of the change in the sum of energies $\delta A(t)+\delta Q(t)$ (value, rate of change of the value, time of exposure to energy and the number of occurrences of energy impacts per unit volume of the material), depending on the structure, humidity, and temperature of the material at the time of exposure, from the point of view of changing the physical properties of the material, and also, from the point of view of changing the mechanical properties of the material. First type of classifications has to describe the probability of the occurrence of irreversible deformation and the impossibility of deformation, and the second has to characterize the probability of the appearance defect and changing the structure of the material.

Thus, the availability of four classifications will allow us to solve the problems of predicting the deformability of railway track elements in time. Next, several types of tasks are considered, the solution of which will be possible.

\section{Examples showing the need of using for additional classifications}

Example 1. Prediction based on the study of the physical nature of the accumulation of contactfatigue rail damage.

To study this issue, complex tests were carried out on the ring of the All-Russian Research Institute of Railway Transport [5]. The test was carried out on a straight section of the track and a curve with a radius of $400 \mathrm{~m}$. During the test, three test cycles were carried out, differing in axial load: 23 , 25 , and $27 t$ /axis. In each cycle was used:

- 100 new identical four-axle wagons loaded with crushed stone;

- three stacking of rails. At the first stacking of the rails, the contact of the wheels and the outer rails was carried out with two-point contact (the tread of the wheels along the surface of the rail and the wheel flange along the inner side surface of the rail). Rails of the second laying provided $60 \%$ of cases with two-point contact and 40 with singlepoint contact (in the upper zone of the working curve of the rail head). The rails of the third stacking provided $85 \%$ movement in a single-point contact with the pressed wheel flange to the side edge of the rail and $15 \%$ in two-point.

In addition, a special experiment was carried out without changing the wear of the wheels, and with changing contact conditions of the wheels and rails due to the difference in the rail canting $1 / 20$, $1 / 40$ and without a rail canting.

As a result of the tests, it was determined that:

- the conditions of wheels and rails contact affect more significantly on the service life of rails than the effect of axial load;

- types of defects on the outer rail of the curves along which the rails failed were characteristic for each rail laying, that is, for a different contact shape. On the rails of the first installation, there were defects in the wear of the head and web of a rail (defects 52.1 - longitudinal cracks at the junction of the rail web with the head and base of a rail, 53.1 - cracks in the rail web from bolt holes, 17.1 - shelling and peeling of metal on the rolling surface) and there was no not a single failure in contact fatigue damage (defects 11 - chipping and peeling of metal on the side working fillet of the rail head and 21 - transverse cracks in the rail head). When operating rails of the second installation, approximately $40 \%$ of failures were due to contact fatigue damage (defects 11 and 21), and when operating rails of the third installation, all failures were due to contact fatigue damage (defects 11 and 21);

- in straight track sections defects 11 and 21 occur many times less often than in curved track sections;

- defects 11 and 21 practically do not occur on the inner rail of the curves.

The conclusions obtained in the test are well explained using the proposed method for elastic waves propagation.

When modeling the movement of a wheelset along a track, it is necessary to take into account the main features of this movement. The movement of the wheelsets is carried out along the track 
along a sinusoid, even with the perfect technical condition of the rails and wheels, as well as the technical condition of the rail track and wheelsets which is caused by the conical shape of the wheel flange. Therefore, the main type of contact of the inner and outer rails with the wheels in straight track sections is a single-point contact (rail rolling surface), but with different contact areas and the direction of the forces acting on these sites. In the curved track sections, the wheelset is shifted to the outer rail, therefore, the contact of the wheels and rails along the inner thread is carried out through a single-point contact between the wheel tread and the rail rolling surface. And on the outer thread, the wheels and rails are in contact at a two-point contact and/or single-point (in the upper zone of the working curvature of the rail head), the ratio of the types of contacts depends on the radius of the curve, the superelevation of the curved track section, as well as on the technical condition of the wheels and rails.

According to the characteristics, rail steel refers to solid-state solid materials, inside which both longitudinal and transverse waves propagate.

In fact, the modelling of the force effect on the contact areas of wheels and rails is complicated by taking into account such temporary aspects of contact as:

- the time of action and the pattern of change of the forces acting between wheels on the rails,

- at two-point contact, there is both the difference in the time of application of forces to each contact area and the offset between the contact areas along the rolling surface and the side surface of the rail, which depends on the angle of attack of the wheel on the rail.

Even without taking into account the indicated complicating parameters, one can state the fact that during single-point contact of wheels and rails, bound atoms or molecules move under the influence of a superposition of two wave processes caused by the propagation of longitudinal and transverse waves. The processes have different propagation velocities, so the longitudinal wave velocity is approximately $5600 \mathrm{~m} / \mathrm{s}$, and the shear wave velocity is $3200 \mathrm{~m} / \mathrm{s}$, respectively. The direction of displacements of bound atoms or molecules under the influence of each type of wave is different (Fig. 1). It is necessary to consider the superposition of two single-point contacts, taking into account the direction of forces acting on each area contact, at two-point contact of wheels and rails. That is the superposition of four-vector processes in time.

In these processes, the energy of the longitudinal waves is expended on processes of changing the volume and shape in the directions of wave propagation, and the energy of the transverse waves to shift the particles to the vacant place. Both types of waves, in this case, characterize the elastic properties of the material, but the energy of the longitudinal waves characterizes the perception of the pulse by the material (its deformability), and the energy of the transverse waves characterizes the elasticity of the bonds of the particles of the material with each other. In addition, in two-point contact, two inelastic impacts of waves will take place when the energy vectors of longitudinal and transverse waves are added.

The next aspect that affects the processes that occur when the wheels and rails interact is the direction of the forces on the contact areas. The direction of these forces characterizes the place of their reflection inside the rail. Such places can be fillets of the rail head (the curvilinear part of the connection of the head and web of the rail), the contours of the web or base of the rails, as well as the opposite side face of the rail head. Reflection sites affect the appearance and parameters of new wave processes. And, according to the theory of propagation of elastic waves, each longitudinal or transverse wave causes four types of waves: two reflected and two refracted. The characteristics of the reflected waves affect the deformation processes inside the rail. Considering the fact that the time of the interaction of wheel and rail section is much longer than the time it takes the waves to travel through the inner space of the rail, it is ultimately necessary to consider the superposition in time both processes of incidence and refraction inside the rail.

However, when studying the physical nature of the accumulation of contact-fatigue injuries of rails, the forces at a single-point contact (in the upper zone of the working curvature of the rail head) are significant, since the distance to the fillet on the opposite side of the rail is much closer than with other contact options. In this case, the magnitude of the influence of force effects is more significant than under the influence of point-to-point 
contact. The time between the effects of the incident and reflected wave processes returning to the point of application of force is less, and the probability of receiving a reflected wave that coincides with the direction of the wave of incidence is higher. Thus, when a wheel contacts a rail on a rounded lateral surface, non-metallic inclusions or bound atoms or a molecule of rail steel encountered in the propagation path of force waves of incidence and reflection will experience tension forces, which also increases the likelihood of deformative changes in the rails.

As indicated above, the maximum value of the force action is transferred by longitudinal waves that coincide in direction with the acting force. Therefore, with two-point contact, the maximum force effects inside the rail will be at the intersection of the wave processes of energy transfer by longitudinal waves that occur at each of the contact areas of the rail and wheel and coincide with the direction of acting forces. But, firstly, the result of the addition of vectors in an inelastic impact is lower than under the action of longitudinal waves, which coincide with the direction of the force during a single-point contact of the wheel with the upper zone of the working curvature of the rail head. Secondly, as indicated when considering the features of the movement of wheels along rails, the intersection of such processes has a lower probability of occurrence, that is, processes occurring inside the rail always occur with fewer deformability changes.

Thus, the application of the method for elastic waves propagation allows us to receive conclusions about the physical nature of the accumulation of contact-fatigue rail damage, which are similar to the conclusions obtained in an experimental study. Expensive tests could have been applied as a tool for verifying changes in the physical and mechanical properties of a material. To sum up, the results of considering the probability of deformability changes in the rail head at various contacts will still remain comparative without knowing about material behavior during deformability process.

Example 2. Prediction based on the study of the physical nature of damage to reinforced concrete sleepers.

The classification of defects in reinforced concrete sleepers contains defect 41 (destruction of concrete), the reason for which is insufficient frost resistance and durability of concrete due to unsuitable starting materials for the sleeper concrete. The defect occurs on the top of the sleepers, on four beveled surfaces that are adjacent to the rail attachment area on both sides Fig. 2, destruction areas 1,2 . These areas do not have a load, such as a rail mounting areas, and do not come into contact with the ballast layer, like the lower part under the areas under consideration, although such defects do not occur on the load transfer surface from the gasket to the sleepers or on the contact surface of the sleepers lower bed. In addition, two areas that are located on the inside of the sleepers (between symmetric areas 2) are interconnected by a connecting part of the same concrete, which also does not undergo this destruction. Therefore, there is bewilderment, why the destruction occurs precisely at these sites. An explanation of this effect can also be demonstrated using the theory of elastic waves propagation, but, as in the previous case, with an example of defects in the rail, without data on material changes, this also remains a qualitative problem.

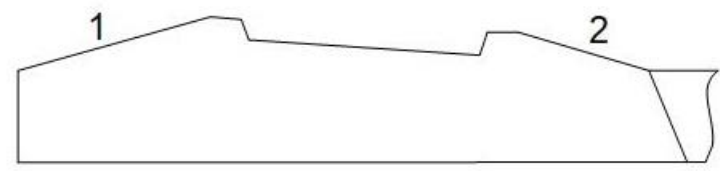

Fig. 2. Destruction areas

Concrete, like metal, belongs to solid-state solid materials, inside which both longitudinal and transverse waves propagate. The rail fastenings have constant contact with the pad, transmitted longitudinal and transverse spherical waves, which move particles as shown in Fig. 1, $a$ and Fig. 1, $b$ into a sleeper. Thus, it is found that the destruction areas 1 and 2 correspond to the directions of propagation of force waves, in which $92 \%$ of the energy is spent on ensuring the movement of particles by the action of transverse waves that are, the particles tend to take the place which the underlying particles freed up by the action of longitudinal waves. Since the particles have a rigid connection with each other, with such a displacement, tension occurs between the particles, which contradicts the functional work of concrete intended for compression work. 
The wave propagation time varies depending on the characteristics of the material. For reinforced concrete sleepers, the longitudinal wave velocity of the concrete $-4000 \mathrm{~m} / \mathrm{s}$, and the shear wave velocity of $2600 \mathrm{~m} / \mathrm{s}$. Longitudinal waves perform compressive efforts in the direction of propagation and make particles to move in this direction. In parallel, two processes occur that have a different focus. In the first process, concrete particles move under the influence of transverse waves into the empty space. The second process involves the movement of concrete particles under the action of reflected longitudinal waves from the reinforcement. Therefore, the destruction of concrete at sites 1 and 2 will be absent if tensile forces under the action of the first process are timely compensated by the compressive forces of the second process.

Thus, the geometric shape of the sleepers, the location of the reinforcement and the physical and mechanical characteristics of concrete and reinforcement, as well as the relationships between them, are components of the deformability process and a change in any of the characteristics forces us to review other characteristics to ensure the safe and functional operation of the sleepers.

Example 3. Prediction based on the study of the physical nature of the accumulation of damage to wooden sleepers

Wood, as a material, refers to solid-state solid materials, but its physical and mechanical characteristics are such that only longitudinal waves propagate inside the material. Moreover, the velocities of longitudinal waves along the fibers in the perpendicular direction to the fibers and in the radial direction are different. The wood fibers in the wooden sleepers are located along the length of the sleepers, and basically, the transverse profile of the wooden sleepers is such that the load from the rail to the sleepers is transmitted in radial directions and at an angle to them. Thus, superimposing Fig. 1, $a$ to the contact areas of the metal pad and sleepers, and we will consider the displacements of bound atoms or molecules of wood under the action of longitudinal waves of a certain direction to the wood fibers.

It was shown in [8] that at different speeds of movement the contact time of the rail and wheel is different, and the lower the speed, the longer the pulse transmission time. The radial velocity of lon- gitudinal waves in a tree is approximately $700 \mathrm{~m} / \mathrm{s}$. The rate of change of momentum per unit time at a rolling stock speed of $2.7 \mathrm{~m} / \mathrm{s}$ is $2.1 \cdot 10^{-5} \mathrm{kN} / \mathrm{s}$, at $16.7 \mathrm{~m} / \mathrm{s}-3.1 \cdot 10^{-6} \mathrm{kN} / \mathrm{s}$, at $33.3 \mathrm{~m} / \mathrm{s}-1.3 \cdot 10^{-6} \mathrm{kN} / \mathrm{s}$. Consequently, when the speed of the rolling stock changed by 6 times, the change in momentum increased by 6.84 times, when the speed of the rolling stock changed by 12 times, the change in momentum increased by 15.74 times. Physically, this means that at the same speed of movement of power waves inside wooden sleepers, the intensity of the energy flow at a point is different, and its value is proportional to the change in the intensity of the pulse.

The intensity of the force fields and the duration of their action affects the interatomic bonds and the destruction of bonds between the bound atoms and molecules of wood. Destroyed wood fibers will create a layer with new physical and mechanical characteristics. The destroyed layer will act as a damper, and its thickness will depend on the intensity value of the force fields that do not lead to the destruction of wood fibers under repeated exposure cycles.

Example 4. Prediction based on the study of the physical nature of the accumulation of damage in soils

Materials such as soils belong to solid-state but bulk materials in which both longitudinal and transverse waves propagate. Saturation of soils with water significantly changes the properties of soils of a small fraction, so when dry, particles in homogeneous soils are single grains of certain fractions of the soil, and not bound atoms or molecules. In this case, the presence of transverse waves determines the amount of energy spent on overcoming the adhesion forces between the particles and friction when moving. If the soil is saturated with water, then the particles are connected atoms or molecules, the bond between which is similar to the work of solid materials.

Also, the saturation of soils with water and the size of the fraction affects the change in the local volume of soils, as a function depending on the density, temperature, and compressibility of the soil, under the action of force waves. So, there are dependencies corresponding to a specific moisture value of a certain value of the soil compaction coefficient. If the soil throughout the volume has the 
corresponding characteristics, these soils are considered compacted and the action of force waves will not cause any physical processes to appear, the waves will pass through the soil thickness until they are completely damped. The behavior of such a layer can indeed be regarded as the behavior of an absolutely rigid body. Under other conditions, various physical processes will take place leading to a change in soil volumes. Therefore, depending on the physical and mechanical characteristics of soils at the time of mechanical action, different scenarios of soil behavior are possible.

In addition, sleepers have certain requirements for deepening into the ballast layer, this leads to the fact that the movement of soil particles occurs under the influence of several force fields, in which each field has its own clear vibration parameters and the impact results of the others. So, at the points of contact between the reinforced concrete sleepers and the ballast layer, in the latter, there are four different power processes, two of which transfer energy with the help of longitudinal waves and two with the help of transverse waves. Even with the same value of the force action from the wheel on the rail but different speeds of motion of rolling stock, the same ballast layer will have different characters and places of concentration of energy of the deformative process, as a result of the superposition of force fields in time. When changing the place of application, the value and direction of the force impact of the wheel on the rail and the same speed of motion of rolling stock, the processes of deformability in the ballast layer will differ too.

Also, if the state of the ballast layer is such that it is possible to tear off the surface of the sleepers from the ballast, in addition to these four power processes, two more processes are added that transfer energy using longitudinal and transverse waves.

In addition, if there is a vibrational effect on the ballast located in a limited box, size of which is smaller than necessary for attenuation of waves, then there are processes of reflection of force fields. These processes also contribute to changes in a local volume.

Given the above processes, when experimenting with vibrational effects on ballast, it is imperative that the results be obtained for certain:

- characteristics of the ballast layer;

- parameters of force impact (frequency of exposure and frequency of reiteration of exposure, as well as the conditions of contact of the stamp and ballast);

- geometric characteristics of the test sample.

Therefore, there is a need to correlate the results obtained in the experiments with the results obtained under actual operating conditions. And for this, data classifications are needed to predict soil deformability over time.

\section{Originality and practical value}

It has been proposed to develop classifications of changes in the material physical properties according to the probability of irreversible deformations and the impossibility of deformations and also classifications of changes in the material mechanical properties, according to the probability of the appearance defect and changing the structure of the material.

The ability to simulate analytically any physical processes occurring inside elements due to the proposed method to allow combining the influence of mechanical and physical effects into a single calculation. That enables to assess the probability of appearing defects in elements under certain dynamic loads when railway track risk assessment over time due to railway track elements' deformability.

\section{Conclusions}

The article is devoted to the study of the deformability processes in the interaction of the railway track and rolling stock and the environmental impact, from the point of view of considering a dynamic problem that requires taking into account changes in the technical conditions of both elements and the design of the railway track.

The work takes into account that:

- the elements and design of the railway track during operation are subjected to a variety of physical and mechanical influences. Their influence is the cause of changes in the physical and mechanical properties of the materials of the elements and the bonds between the track design elements.

- the processes of deformability are determined by the second limiting state, by definition, unsuitability for normal operation, so it became necessary to have additional data on the behavior of the track design elements. 
For this purpose, it is proposed to apply the theory of elastic waves propagation and replace the model of the material as a continuum with the model of the material as a discrete substance. The changes introduced in the simulation made it possible to apply the basic law of dynamics and the first law of thermodynamics for the internal volume of the track design elements.

Based on these laws, the need is formulated to classify the parameters of the change in the sum of energies as for changes:

- physical properties of the material in terms of the probability of irreversible deformation and the impossibility of deformation;
- mechanical properties of the material in the probability of the appearance defect and changing the structure of the material.

Application of the method made it possible to show the importance of knowledge of the data on the behaviour of materials of railway track elements during operation using examples of the appearance of local damage and changes caused by the action of local processes. That will provide to expand data on changes in the material behaviour under dynamic loads when railway track risk assessment over time due to railway track elements deformability.

\section{LIST OF REFERENCE LINKS}

1. Баб'як М. О. Експлуатація ресурсозберігаючих контактних елементів міського електричного транспорту. Вісник Східноукраӥнського начіонального університету ім. В. Даля. 2019. № 3 (251). С. 33-38.

2. Бондаренко И. А. Концепция детализации как способ повышения конкурентоспособности железнодорожного транспорта. Строительство, материаловедение, машиностроение. 2018. Вып. 106. С. 14-19.

3. Бондаренко I. О. Моделювання з метою встановлення оціночних умов функціональної безпеки залізничної колії. Східно-Свропейський журнал передових технологій. 2016. Т. 1, № 7 (79). С. 4-10. DOI: http://doi.org/10.15587/1729-4061.2016.59874

4. Зеленько Ю. В., Зеленько Д. М., Недужа Л. О. Вивчення негативного впливу нафтопродуктів на металеві елементи залізничної інфраструктури. Наука та прогрес транспорту. 2020. № 5 (89). С. $103-113$. DOI: https://doi.org/10.15802/stp2020/218353

5. Лысюк В. С., Каменский В. Б., Башкатова Л. В. Надежность железнодорожного пути. Москва : Транспорт, 2001. 286 с.

6. Фомін О. В., Ловська А. О., Горбунов М. І., Фоміна Ю. В. Визначення поздовжньої навантаженості несучої конструкції вагона-платформи, завантаженого контрейлером. Наука та прогрес транспорту. 2020. № 4 (88). C. 103-113. DOI: https://doi.org/10.15802/stp2020/213449

7. Accattatis F. M. D., Bruner M., Crisi F., D’Ovidio G., Valente G., Vitali P. Railway vehicle dynamics and the soil vibration analysis. Conference : 2nd International Workshop Diss_12 «Dynamic Interaction of Soil and Structure». 2014. P. 161-176.

8. Bondarenko I. Development of algorithm for calculating dynamic processes of railroad track deformability work. Eastern-European Journal of Enterprise Technologies. 2016. Vol. 6. Iss. 7 (84). P. 28-36. DOI: http://doi.org/10.15587/1729-4061.2016.85464

9. Bondarenko I., Keršys R., Lunys O., Neduzha L. Dynamic Track Irregularities Modeling when Studying Rolling Stock Dynamics. Proc. of 23rd Intern. Sci. Conf. (Palanga, 2-4 oct., 2019). Kaunas University of Technology. Palanga, 2019. P. 1014-1019.

10. Bondarenko I. O., Neduzha L. O. Investigation of the Influence of the Rolling Stock Dynamics on the Intensity of Using of the Railway Track Elements. Science and Transport Progress. 2019. № 4 (82). P. 61-73. DOI: https://doi.org/10.15802/stp2019/176661

11. Csépke R. Wheel-Rail Interface in narrow curves. Proceedings of the 10th International Conference on Railway Bogies and Running Gears - Department of Rolling Stock of the Scientific Society of Mechanical Engineers : Conference Paper (Budapest, 12-15 sept. 2016). Budapest, 2016. P. 297-305.

12. Ershova N., Bondarenko I., Shibko O., Velmagina N. Development of the procedure for verifying the feasibility of designing an active suspension system for transport carriages. Eastern-European Journal of Enterprise Technologies. 2018. Vol. 3. Iss. 7 (93). P. 53-63. DOI: http://doi.org/10.15587/17294061.2018.131534

13. Górka W., Baginski J., Socha M., Stęclik T., Leśniak D., Wojtas M., Flisiuk B., Michalak M. Cloud Decision Support System for Risk Management in Railway Transportation. Proceedings of 14th International Conference on Software Technologies. 2019. Vol. 1. P. 475-482. DOI: https://doi.org/10.5220/0007837904750482 
14. Kalivoda J., Neduzha L. Simulation of Safety Against Derailment Tests of an Electric Locomotive. Engineering Mechanics 2019 : Proceedings of 25th International Conference (Svratka, 13-16 May 2019). Svratka, 2019. P. 177-180. DOI: https://doi.org/10.21495/71-0-177

15. Karliński J., Ptak M., Chybowski L. Simulation-Based Methodology for Determining the Dynamic Strength of Tire Inflation Restraining Devices. Energies. 2020. Vol. 13. Iss. 4. P. 1-14. DOI: https://doi.org/10.3390/en13040991

16. Klimenko I., Kalivoda J., Neduzha L. Speed Influence of Parameters of Electric Locomotive on its Critical. TRANSBALTICA XI : Transportation Science and Technology. 2020. P. 531-540. DOI: https://doi.org/10.1007/978-3-030-38666-5_56

17. Kondratiev A., Gaidachuk V., Nabokina T., Tsaritsynskyi A. New possibilities in creating of effective composite size-stable honeycomb structures designed for space purposes. Integrated Computer Technologies in Mechanical Engineering. 2020. P. 45-59. DOI: https://doi.org/10.1007/978-3-030-37618-5_5

18. Lee C. S., Bourdage J. S. Risk Taking. The Wiley Encyclopedia of Personality and Individual Differences. 2020. P. 363-367. DOI: https://doi.org/10.1002/9781118970843.ch239

19. Rzeczycki A., Wiśnicki B. Strength Analysis of Shipping Container Floor with Gooseneck Tunnel under Heavy Cargo Load. Solid State Phenomena. 2016. Vol. 252. P. 81-90.

DOI: https://doi.org/10.4028/www.scientific.net/ssp.252.81

20. Skrucany T., Semanova S., Milojević S., Ašonja A. New Technologies Improving Aerodynamic Properties of Freight Vehicles. Applied Engineering Letters : Journal of Engineering and Applied Sciences. 2019. Vol. 4. Iss. 2. P. 48-54. DOI: https://doi.org/10.18485/aeletters.2019.4.2.2

21. Strážoveca P., Gerlicia J., Lacka T, Harušinec J. Innovative solution for experimental research of phenomena resulting from the wheel and rail rolling. Transportation Research Procedia. 2019. Vol. 40. P. 906-911. DOI: https://doi.org/10.1016/j.trpro.2019.07.127

22. Tatarinova V. A., Kalivoda J., Neduzha L. O. Research of Locomotive Mechanics Behavior. Science and Transport Progress. 2018. № 5 (77). P. 104-114. DOI: https://doi.org/10.15802/stp2018/148026

23. Trubia S., Severino A., Curto S., Arena F., Pau G. Smart Roads : An Overview of What Future Mobility Will Look Like. Infrastructures. 2020. Vol. 5. Iss. 12. P. 1-12. DOI: https://doi.org/10.3390/infrastructures5120107

24. Tsiavos A., Mackie K. R., Vassiliou M. F., Stojadinovic B. Dynamics of inelastic base-isolated structures subjected to recorded ground motions. Bulletin of Earthquake Engineering. 2017. Vol. 15. Iss. 4. P. 1807-1830. DOI: https://doi.org/10.1007/s10518-016-0022-5

25. Wajda L., Duda-Chodak A., Tarko T., Kamiński P. Application of principal component analysis for the optimisation of lead (II) biosorption. World Journal of Microbiology and Biotechnology. 2017. Vol. 33. Iss. 10. P. 1-10. DOI: https://doi.org/10.1007/s11274-017-2358-7

26. Zhuravlev A., Razevig V., Ivashov S., Skrebkov A., Alekseev V. On the Use of Microwave Holography to Detectsurface Defects of Rails and Measure the Rail Profile. Sensors. 2019. Vol. 19. Iss. 6. P. 1-11. DOI: https://doi.org/10.3390/s19061376

\section{І. О. БОНДАРЕНКО ${ }^{*}$, Л. О. НЕДУЖА ${ }^{2 *}$}

\footnotetext{
1*Каф. «Колія та колійне господарство», Дніпровський національний університет залізничного транспорту імені академіка В. Лазаряна, вул. Лазаряна, 2, Дніпро, Україна, 49010, тел. +38 (063) 80221 80, ел. пошта irina_bondarenko@ua.fm, ORCID 0000-0003-4717-3032

2*Каф. «Теоретична та будівельна механіка», Дніпровський національний університет залізничного транспорту імені академіка В. Лазаряна, вул. Лазаряна, 2, Дніпро, Україна, 49010, тел. +38 (067) 81051 65, ел. пошта nlorhen@i.ua, ORCID 0000-0002-7038-3006
}

\section{ПРОБЛЕМА ВІДСУТНОСТІ ДАНИХ ПРО ПОВЕДІНКУ МАТЕРІАЛІВ ДЛЯ ОЦІНКИ РИЗИКУ}

Мета. Основна мета цієї роботи - надати теоретичне обгрунтування необхідності розширення даних про зміну поведінки матеріалів під час динамічних навантажень для оцінки ризику залізничної колії 3 часом унаслідок деформативності ії елементів. Методика. Для дослідження було використано оригінальну модель конструкції залізничної колії, описану за допомогою оригінальної методики, заснованої на здатності пружних хвиль поширювати енергію силових імпульсів у просторі та часі, а також модель, що описує матеріали як дискретні речовини. Результати. Установлено, що властивості матеріалів впливають на деформативність Creative Commons Attribution 4.0 International 
елементів та конструкцію залізничної колії; основним параметром під час вивчення процесів деформативності є час; матеріал як речовина складається з атомів і молекул, а отже, не є суцільним; внутрішні фізичні процеси визначають зміни в поведінці матеріалу елемента. Наукова новизна. Запропоновано розробити класифікації змін фізичних властивостей матеріалів за ймовірністю появи незворотних деформацій та неможливістю деформацій, а також класифікації змін механічних властивостей матеріалів за ймовірністю появи дефекту та зміною структури матеріалів. Практична значимість. Можливість аналітичного моделювання будь-яких фізичних процесів, що відбуваються всередині елементів, завдяки запропонованому методу дозволяє поєднати вплив механічних та фізичних дій в одному розрахунку. Це сприяє встановленню ймовірності появи дефектів елементів за певних динамічних навантажень для оцінки ризику залізничної колії 3 часом через деформативність ії елементів.

Ключові слова: ризик; деформації; матеріали; дефект; деформативність; фізико-механічні характеристики

\section{И. А. БОНДАРЕНКО ${ }^{1 *}$, Л. А. НЕДУЖАЯ ${ }^{2 *}$}

\footnotetext{
${ }^{1 *}$ Каф. «Путь и путевое хозяйство», Днипровский национальный университет железнодорожного транспорта имени академика В. Лазаряна, ул. Лазаряна, 2, Днипро, Украина, 49010, тел. +38 (063) 80221 80, эл. почта irina_bondarenko@ua.fm, ORCID 0000-0003-4717-3032

2*Каф. «Теоретическая и строительная механика», Днипровский национальный университет железнодорожного транспорта имени академика В. Лазаряна, ул. Лазаряна, 2, Днипро, Украина, 49010, тел. +38 (067) 8105165 , эл. почта nlorhen@i.ua, ORCID 0000-0002-7038-3006
}

\section{ПРОБЛЕМА ОТСУТСТВИЯ ДАННЫХ О ПОВЕДЕНИИ МАТЕРИАЛОВ ДЛЯ ОЦЕНКИ РИСКА}

Цель. Основная цель данной работы - теоретическое обоснование необходимости расширения данных об изменении поведения материалов при динамических нагрузках для оценки риска железнодорожного пути с течением времени из-за деформативности его элементов. Методика. Для исследования использовалась оригинальная модель конструкции железнодорожного пути, описанная с помощью оригинальной методики, основанной на способности упругих волн распространять энергию силовых импульсов в пространстве и времени, а также модели, описывающей материалы как дискретные вещества. Результаты. Установлено, что свойства материалов влияют на деформативность элементов и конструкцию железнодорожного пути; основным параметром при исследовании процессов деформативности является время; материал как вещество состоит из атомов и молекул и поэтому не является непрерывным; внутренние физические процессы определяют изменения в поведении материала элемента. Научная новизна. Предложено разработать классификации изменений физических свойств материалов по вероятности необратимых деформаций и невозможности деформаций, а также классификации изменений механических свойств материалов по вероятности появления дефекта и изменения структуры материалов. Практическая значимость. Возможность аналитического моделирования любых физических процессов, происходящих внутри элементов, благодаря предложенному методу позволяет объединить влияние механических и физических воздействий в единый расчет. Это способствует определению вероятности появления дефектов в элементах при определенных динамических нагрузках при оценке риска железнодорожного пути с течением времени из-за деформативности его элементов.

Ключевые слова: риск; деформации; материалы; дефект; деформативность; физико-механические характеристики

\section{REFERENCES}

1. Babyak, M. (2019). Operation of Resource-Saving Contact Elements of Urban Electric Transport. Visnik of V. Dahl East Ukrainian National University, 3(251), 33-38. (in Ukranian)

2. Bondarenko, I. A. (2018). Concept of detailization as a method of increasing the competitiveness of railway transport. Construction, material science, mechanical engineering, 106, 14-19. (in Russian)

3. Bondarenko, I. O. (2016). Modeling for establishment of evaluation conditions of functional safety of the railway track. Eastern-European Journal of Enterprise Technologies, 1(7(79)), 4-10.

DOI: http://doi.org/10.15587/1729-4061.2016.59874 (in Ukrainian)

Creative Commons Attribution 4.0 International

doi: https://doi.org/10.15802/stp2020/223526

(C) I. O. Bondarenko, L. O. Neduzha, 2020 
4. Zelenko, Y. V., Zelenko, D. M., \& Neduzha, L. O. (2020). Study of negative influence of petroleum products on metal elements of railway infrastructure. Science and Transport Progress, 5(89), 103-113. DOI: https://doi.org/10.15802/stp2020/218353 (in Ukranian)

5. Lysyuk, V. S., Kamenskiy, V. B., \& Bashkatova, L. V. (2001). Nadezhnost zheleznodorozhnogo puti. Moscow: Transport. (in Russian)

6. Fomin, O. V., Lovska, A. O., Horbunov, M. I., \& Fomina, Y. V. (2020). Determination of the longitudinal load of supporting structure of the flat car loaded with a piggyback. Science and Transport Progress, 4(88), 103-113. DOI: https://doi.org/10.15802/stp2020/213449 (in Ukranian)

7. Accattatis, F. M. D., Bruner, M., Crisi, F., D’Ovidio, G., Valente, G., \& Vitali, P. (2014). Railway vehicle dynamics and the soil vibration analysis. Conference: 2 nd International Workshop Diss_12 «Dynamic Interaction of Soil and Structure» (pp. 161-176). (in English)

8. Bondarenko, I. (2016). Development of algorithm for calculating dynamic processes of railroad track deformability work. Eastern-European Journal of Enterprise Technologies, 6(7(84)), 28-36. DOI: http://doi.org/10.15587/1729-4061.2016.85464 (in English)

9. Bondarenko, I., Keršys, R., Lunys, O., \& Neduzha, L. (2019). Dynamic Track Irregularities Modeling when Studying Rolling Stock Dynamics. In Proceedings of 23rd International Scientific Conference (pp. 1014-1019). Palanga. (in English)

10. Bondarenko, I. O., \& Neduzha, L. O. (2019). Investigation of the Influence of the Rolling Stock Dynamics on the Intensity of Using of the Railway Track Elements. Science and Transport Progress, 4(82), 61-73. DOI: https://doi.org/10.15802/stp2019/176661 (in English)

11. Csépke, R. (2016). Wheel-Rail Interface in narrow curves. Proceedings of the 10th International Conference on Railway Bogies and Running Gears-Department of Rolling Stock of the Scientific Society of Mechanical Engineers: Conference Paper (pp. 297-305). Budapest, Hungary. (in English)

12. Erhova, N., Bondarenko, I., Shibko, O., \& Velmagina, N. (2018). Development of the procedure for verifying the feasibility of designing an active suspension system for transport carriages. Eastern-European Journal of Enterprise Technologies, 3(7(93)), 53-63. DOI: http://doi.org/10.15587/1729-4061.2018.131534 (in English)

13. Górka, W., Bagiński, J., Socha, M., Steclik, T., Leśniak, D., Wojtas, M., ... Michalak, M. (2019). Cloud Decision Support System for Risk Management in Railway Transportation. Proceedings of the 14th International Conference on Software Technologies, 1, 475-482. DOI: https://doi.org/10.5220/0007837904750482 (in English)

14. Kalivoda, J., \& Neduzha, L. O. (2019). Simulation of Safety Against Derailment Tests of an Electric Locomotive. Engineering Mechanics 2019: Proc. of 25th Intern. Con Proceedings of 25th International Conference (pp. 177-180). DOI: https://doi.org/10.21495/71-0-177 (in English)

15. Karliński, J., Ptak, M., \& Chybowski, L. (2020). Simulation-Based Methodology for Determining the Dynamic Strength of Tire Inflation Restraining Devices. Energies, 13(4), 1-14. DOI: https://doi.org/10.3390/en13040991 (in English)

16. Klimenko, I., Kalivoda, J., \& Neduzha, L. (2020). Influence of Parameters of Electric Locomotive on its Critical Speed. In TRANSBALTICA XI: Transportation Science and Technology (pp. 531-540). DOI: https://doi.org/10.1007/978-3-030-38666-5_56 (in English)

17. Kondratiev, A., Gaidachuk, V., Nabokina, T., \& Tsaritsynskyi, A. (2020). New possibilities in creating of effective composite size-stable honeycomb structures designed for space purposes. Integrated Computer Technologies in Mechanical Engineering (pp. 45-59). DOI: https://doi.org/10.1007/978-3-030-37618-5_5 (in English)

18. Lee, C. S., \& Bourdage, J. S. (2020). Risk Taking. The Wiley Encyclopedia of Personality and Individual Differences (pp. 363-367). DOI: https://doi.org/10.1002/9781118970843.ch239 (in English)

19. Rzeczycki, A., \& Wiśnicki, B. (2016). Strength Analysis of Shipping Container Floor with Gooseneck Tunnel under Heavy Cargo Load. Solid State Phenomena, 252, 81-90. DOI: https://doi.org/10.4028/www.scientific.net/ssp.252.81 (in English)

20. Skrucany, T., Semanova, S., Milojević, S., \& Ašonja, A. (2019). New Technologies Improving Aerodynamic Properties of Freight Vehicles. Applied Engineering Letters: Journal of Engineering and Applied Sciences, 4(2), 48-54. DOI: https://doi.org/10.18485/aeletters.2019.4.2.2 (in English)

21. Strážovec, P., Gerlici, J., Lack, T., \& Harušinec, J. (2019). Innovative solution for experimental research of phenomena resulting from the wheel and rail rolling. Transportation Research Procedia, 40, 906-911. DOI: https://doi.org/10.1016/j.trpro.2019.07.127 (in English) 
22. Tatarinova, V. A., Kalivoda, J., \& Neduzha, L. O. (2018). Research of Locomotive Mechanics Behavior. Science and Transport Progress, 5(77), 104-114. DOI: https://doi.org/10.15802/stp2018/148026 (in English)

23. Trubia, S., Severino, A., Curto, S., Arena, F., \& Pau, G. (2020). Smart Roads: An Overview of What Future Mobility Will Look Like. Infrastructures, 5(12), 1-12. DOI: https://doi.org/10.3390/infrastructures5120107 (in English)

24. Tsiavos, A., Mackie, K. R., Vassiliou, M. F., \& Stojadinović, B. (2016). Dynamics of inelastic base-isolated structures subjected to recorded ground motions. Bulletin of Earthquake Engineering, 15(4), 1807-1830. DOI: https://doi.org/10.1007/s10518-016-0022-5 (in English)

25. Wajda, L., Duda-Chodak, A., Tarko, T., \& Kamiński, P. (2017). Application of principal component analysis for the optimisation of lead (II) biosorption. World Journal of Microbiology and Biotechnology, 33(10), 1-10. DOI: https://doi.org/10.1007/s11274-017-2358-7 (in English)

26. Zhuravlev, A., Razevig, V., Ivashov, S., Skrebkov, A., \& Alekseev, V. (2019). On the Use of Microwave Holography to Detectsurface Defects of Rails and Measure the Rail Profile. Sensors, 19(6), 1-11. DOI: https://doi.org/10.3390/s19061376 (in English)

Received: August 10, 2020

Accepted: December 11, 2020 